\title{
INVERTIBILITY ALONG AN OPERATOR
}

\section{Gabriel Kantún-Montiel And SlavišA V. DJordjeVić}

Abstract. We study the inverse along an element in the case of the algebra of bounded linear operators on a Banach space and characterize it as an outer inverse with prescribed range and nullspace. This inverse generalizes the group, Drazin and Koliha-Drazin inverses.

Mathematics subject classification (2010): 15A09, 47A05.

Keywords and phrases: Generalized inverse, Drazin inverse, bounded linear operator.

\section{REFERENCES}

[1] D. S. DJORDJEVIĆ AND V. RAKoČEvić, Lectures on generalized inverses, University of Niš, Faculty of Sciences and Mathematics, Niš, 2008.

[2] X. MARY, On generalized inverses and Green's relations, Linear Algebra Appl. 434, 8 (2011), 1836 1844.

[3] X. MARY, Natural generalized inverse and core of an element in semigroups, rings and Banach and Operator Algebras, Eur. J. Pure Appl. Math. 5, 2 (2012), 160-173. 